\title{
Can Adolescents Acquire Cultural Capital Through Social Capital Access and Exposure? Longitudinal Experimental Evidence of the Impact of Ties to College-Educated Adults
}

\author{
S. Michael Gaddis \\ mgaddis@soc.ucla.edu \\ Assistant Professor \\ Department of Sociology \\ UCLA \\ Joseph Murphy \\ jcmurph@g.ucla.edu \\ Graduate Student \\ Department of Sociology \\ UCLA
}

\section{February 2022 Draft}

Abstract: Scholarly debate focuses on whether cultural capital reproduces existing inequalities or provides a path to upward mobility. Most research, however, focuses only on cross-sectional associations and is unclear about how disadvantaged adolescents can increase their amounts of cultural capital. Traditionally, most adolescents' interactions with adults occur across two axes of socialization: families and schools. Families provide opportunities to increase cultural capital while schools value and reward cultural capital. Thus, if adolescents do not obtain cultural capital through their families, they may be at a significant disadvantage when navigating the education system. We hypothesize that adolescents may be able to increase cultural capital through valuable social capital access and exposure - their ties to and meeting frequency with other important adults with knowledge of the education system. We investigate this topic using experimental longitudinal data on mentoring relationships. We find that high levels of social capital access and exposure positively affect cultural capital, but only for adolescents with highly educated parents. Our findings suggest that cultural capital may not be an engine of social mobility if adolescents from low-SES households cannot acquire or increase their cultural capital.

Keywords: cultural capital, social capital, educational inequality, socioeconomic status

Acknowledgements: Thanks to Megan Holland, Karly Ford, and Bill Carbonaro for feedback on this paper.

Corresponding author: S. Michael Gaddis, University of California, Los Angeles (UCLA), Department of Sociology, 285 Haines Hall, Los Angeles, CA 90095, 213-406-7580, mgaddis@soc.ucla.edu 


\section{INTRODUCTION}

Cultural capital has become one of the most studied concepts in the social sciences, spanning research on education, inequality, the family, organizations, race, and technology. ${ }^{1}$ Cultural capital consists of assets, cultural knowledge, and linguistic competencies, all deployed with confidence and seeming naturalness that help adolescents navigate the education system (Calarco 2018; Holland 2019; Lareau 2015; Richards 2020a). Teachers, administrators, and other institutional agents value and reward students who exhibit high levels of cultural capital.

Scholars argue that cultural capital matters because it aids students in negotiating interactions with gatekeepers at every educational juncture: with their grade-school teachers (Calarco 2011, 2014), in college admissions offices (Stevens 2007), and with college professors (Jack 2019). Thus, cultural capital plays a vital role in adolescents' and young adults' educational achievement and attainment, where they go to college, and their later socioeconomic status (Gaddis 2015; Lee and Kramer 2013; Noble and Davies 2009; Nora 2004; Rivera 2011, 2012).

Over time, cultural capital research has splintered into multiple paths and led to disputes about interpreting and operationalizing the concept and whether cultural capital contributes to socioeconomic reproduction or mobility (see (Davies and Rizk 2018; Hu and Yin 2020; Lareau and Weininger 2003)). We argue that the literature contains at least two other significant blindspots. First, education scholars incorporate a view of cultural capital that nearly exclusively examines the nexus between families and schools. This view ignores students' potential cultural capital acquisition that might come from other adults outside these institutions. Second, research is often cross-sectional and presents a simple point-in-time snapshot of adolescents' cultural capital. Unable to capture changes over time, this research lacks details about when, where, and

\footnotetext{
${ }^{1}$ We conducted a Google Scholar search for research using the term "cultural capital" in the title and found that scholars have published over 2,200 articles and books on this topic in the past five years. 
how adolescents might acquire or increase their amounts of cultural capital. These two shortcomings significantly limit our understanding of whether cultural capital is an engine of social mobility or reproduction.

We hypothesize that adolescents, particularly disadvantaged adolescents, may be able to gain cultural capital through social capital. Broadly conceived, social capital represents the resources - information, knowledge, and opportunities - embedded in networks and relationships (Lin 2002, 2008; Portes 1998; Smith 2008). Access and repeated exposure to college-educated adults who have successfully navigated the education system may help adolescents increase their cultural capital. This form of social capital may be particularly valuable to adolescents with noncollege-educated parents because it may provide adolescents with their first close ties to a college-educated adult outside of school. However, similar to research on cultural capital, research on social capital in education has rarely focused on ties between adolescents and adults outside of family or school networks (although, see (Gaddis 2012; Hofferth, Boisjoly, and Duncan 1998; Morgan and Sørensen 1999)).

We examine whether adolescents' access and exposure to social capital increase cultural capital and whether this relationship varies by parents' educational attainment. We investigate this topic using unique experimental longitudinal data on mentoring relationships between adolescents and adults in the Big Brothers/Big Sisters of America program. In our dataset, program staff randomly assigned adolescents to a control group with no contact with a mentor or a treatment group that paired them in a mentoring relationship with an outside adult for 18 months. We operationalize social capital access as: (1) no mentor, (2) mentor with some college education (but no degree) or less, and (3) mentor with a college degree or more. Additionally, we operationalize social capital exposure as the frequency of meetings between adolescents and their 
mentors. Our dataset also includes a battery of adolescent, family, and mentor characteristics recorded at baseline and 18 months later. We control for baseline cultural capital and examine the effects of social capital access and exposure on six measures of cultural capital as discussed in both quantitative and qualitative research: (1) reading habits, (2) museum attendance, (3) play attendance, (4) cultural lessons, (5) visiting cultural locations, and (6) relationships with teachers.

In our initial models of social capital access, we find that access to a mentor has positive effects on adolescents’ cultural capital but only when a mentor has a college degree or greater. When we include a measure of social capital exposure (meeting frequency) in our models, we find that most of the positive effects are concentrated among adolescents with highly educated mentors who meet with adolescents frequently. Finally, when we examine differential effects by parental education, we find that all of the positive effects of social capital access and exposure on cultural capital occur among adolescents with a parent with high educational attainment.

Our research merges multiple theoretical strands and provides strong causal evidence on the effects of social access and exposure on cultural capital. The results suggest that social capital access and exposure can induce changes in cultural capital, but the benefits are limited to adolescents with highly educated parents. This research raises doubts about whether adolescents from disadvantaged households can increase their amounts of cultural capital valued by dominant middle-class institutions. More broadly, our findings implicate cultural capital in a system of social reproduction.

\section{LITERATURE REVIEW}

\section{Forty-Five Years of Cultural Capital Research}

Scholars have broadly interpreted the work of Pierre Bourdieu (1984, 1986; Bourdieu and Passeron 1977) to suggest that inequalities in capital (e.g., human, social, and cultural) lead to 
inequalities in academic outcomes. Cultural capital is the "informal knowledge about school, traditional humanist culture, linguistic competence and specific attitudes, or personal style” that are the attributes of the dominant class (Lamont and Lareau 1988: 155). Bourdieu's theory of cultural reproduction suggests that gatekeepers can limit the social mobility of individuals who do not display cultural capital. Teachers, administrators, and other actors in educational environments value cultural characteristics that align with the dominant middle-class culture. Advantaged students convey this culture through speech, attitudes, behavior, knowledge, and other interactions. However, only adolescents from middle- and high-SES backgrounds are exposed to the necessary cultural capital through their home life, interactions with their parents, and the various activities encouraged or organized by their parents. Although cultural capital helps these adolescents navigate the education system, adolescents from low-SES backgrounds may not have the dominant cultural capital expected at school and are at a distinct disadvantage. Thus, schools reproduce inequalities based on SES because institutional agents reward displays of the dominant culture, and those rewards translate into higher levels of educational achievement and attainment.

A dividing line exists between quantitative and qualitative researchers' approaches to cultural capital. Quantitative researchers tend to operationalize cultural capital as measures of cultural resources. The most common operationalizations include reading habits and participation in high-arts activities, such as museum visits and play attendance (Breinholt and Jæger 2020; De Graaf, De Graaf, and Kraaykamp 2000; Gaddis 2013). ${ }^{2}$ Qualitative researchers

\footnotetext{
${ }^{2}$ Numerous additional operationalizations appear in the literature, including beaux-arts possessions (Aschaffenburg and Maas 1997; DiMaggio 1982; Jæger 2009), cultural classes or lessons (Dumais 2008; Dumais and Ward 2010; Wildhagen 2009), cultural discussions and knowledge (Dimaggio and Mohr 1996; Jæger 2009; Tramonte and Willms 2010), extracurricular activities (Covay and Carbonaro 2010; Jæger 2011), and teacher perceptions of habits and skills (Farkas 2017; Farkas et al. 1990; Kozlowski 2015). Some scholars have expanded quantitative measures to better capture concepts from the qualitative literature (Dumais, Kessinger, and Ghosh 2012; Dumais and Ward 2010; Matsuoka 2019).
} 
consider cultural capital as parents' and children's translation of knowledge, practices, and habits into educational opportunities and success. This translation can occur through middle-class families “working the system” (Lareau 2000), increasing children’s opportunities and confidence in interactions with institutional agents (Lareau 2011, 2015), or children's help-seeking strategies (Calarco 2011, 2014, 2018; Streib 2011). ${ }^{3}$

\section{Can Adolescents Acquire or Increase Amounts of Cultural Capital?}

While researchers generally find that cultural capital is a crucial component in educational inequality, it remains unclear whether it contributes to reproduction or mobility (Aschaffenburg and Maas 1997; DiMaggio 1982). Perhaps this lack of clarity is due to limited research addressing whether cultural capital can be acquired or increased (Hu and Yin 2020). Qualitative and quantitative research on cultural capital have advantages and disadvantages in addressing this point. Qualitative research captures cultural capital as a relational concept better than quantitative research (Davies and Rizk 2018). However, while qualitative researchers examine the interaction processes leading to the use of cultural capital, they do not measure amounts of cultural capital nor find that adolescents from lower- and working-class families can systematically obtain cultural capital. Conversely, although quantitative research theoretically can examine changes in amounts of cultural capital, most studies examine cross-sectional rather than longitudinal data.

A limited number of studies provide some insight about whether and how adolescents can obtain or increase amounts of cultural capital. Two such qualitative studies stand out. The first

\footnotetext{
3 The resulting social class inequalities from this form of cultural capital continue into higher education, leading to fewer strategies for first-generation students to draw upon while navigating college (Armstrong and Hamilton 2013; Jack 2016; Stuber 2011; Yee 2016). Without sufficient cultural capital, these students face a form of "culture shock," which increases stress and sense of isolation and places them at higher risk of dropping and stopping out (Aries 2008; Jack 2014; Lehmann 2014; Stephens et al. 2012; Zarifa et al. 2018).
} 
examines how cross-class cultural mentors may provide working-class families with resources and tools for interacting with educational institutional agents (Lareau and Calarco 2012). While working-class families sometimes have opportunities to interact with middle- and upper-class parents in a consistent and sustained environment (e.g., during Little League games), these interactions yield limited benefits. A second qualitative study examines how low-SES students interact with educational institutional agents in college (Jack 2016). This research suggests that low-SES students can gain cultural capital when exposed to upper-class peers exhibiting cultural capital at elite prep schools. This form of cultural capital benefits low-SES students by preparing them for interactions with professors and administrators in higher education.

Additionally, three quantitative studies provide insight on whether students can acquire or increase cultural capital. Using the multi-wave longitudinal Panel Study of Income Dynamics (PSID), Roksa and Potter (2011) examine differences in cultural capital among parents whose class positions changed or stayed the same over their lifetimes. They find that upwardly mobile (from low- to middle-SES) parents can adopt practices of concerted cultivation and help their children gain cultural capital. Two field experiments provide strong causal evidence suggesting that adolescents can acquire and increase cultural capital. In the first, students randomly assigned to attend an art museum were more likely than students in the control group to want to acquire more cultural capital and attend the same museum again (Kisida, Greene, and Bowen 2014). In the second, students randomly assigned to attend a theatre play were more likely than students in the control group to want to acquire more cultural capital (Greene et al. 2018).

These five studies provide insight into whether adolescents can acquire or increase amounts of cultural capital but are far from definitive. While the two qualitative and two experimental studies examine potential causal mechanisms of cultural capital acquisition, the 
fifth study (Roksa and Potter 2011) does not specify precisely how cultural capital acquisition might occur. Each of the other four studies examines only a specific mechanism through which adolescents might acquire or increase cultural capital. Moreover, each study examines a specific context - two in northwest Arkansas (Greene et al. 2018; Kisida et al. 2014).

\section{Acquiring or Increasing Cultural Capital through Social Capital}

Although not systematically investigated, the literature on cultural capital acquisition hints at a possible way for parents and adolescents to acquire or increase cultural capital. In the proper context, connections to and interactions with middle- and upper-SES adults might help adolescents acquire or increase cultural capital. These connections are a form of social capital, which scholars define as access to and use of resources available in network connections (Bourdieu 1986; Coleman 1988, 1994; Lin 2002, 2008; Portes 1998). Broad use of social capital in research across fields has led to large variation in measurement of the concept (Jackson 2020; Kwon and Adler 2014; Lakon, Godette, and Hipp 2008; Van der Gaag and Snijders 2004). ${ }^{4}$ Research on social capital in the education literature originates from Pierre Bourdieu's (1986) and James Coleman's (1988) theoretical and empirical work. The former focuses on access to institutional resources, while the latter focuses on norms (Dika and Singh 2002). ${ }^{5}$ Research in the employment and networks literature defines social capital as the resources embedded in networks, relationships, and social ties (Lin 2002; Portes 1998). We merge these important strands of social capital research and focus on two main components of social capital: access and

\footnotetext{
${ }^{4}$ This literature examines social capital at micro- (i.e., individual), meso- (i.e., communities and organizations), and macro-levels (i.e., societies). In this article, we focus on social capital solely at the individual level.

${ }^{5}$ Scholars have operationalized social capital in the education literature in a variety of ways, including intergenerational closure (Carbonaro 1998; Morgan and Sørensen 1999), parents’ relationships with other adults (Horvat, Weininger, and Lareau 2003), parents’ involvement at school (McNeal 1999; Ream and Palardy 2008), adolescents' extracurricular activities (Broh 2002), or resources through adolescents' friends (Cherng, Calarco, and Kao 2013).
} 
exposure. Our inequality- and network-centered theory of social capital helps illuminate important potential mechanisms of cultural capital acquisition.

\section{Social Capital Access}

Social capital access represents both the existence of a tie to another person and the potential resources that can be extracted through that tie. Education scholars who examine social capital often measure access as connections between students and important adults. One critical example is Ricardo Stanton-Salazar's work (1997, 2001, 2011; Stanton-Salazar and Dornbusch 1995), which focuses on social capital access as institutional agents. Stanton-Salazar suggests that teachers, counselors, and anyone else who has "the capacity and commitment to transmit directly, or negotiate the transmission of, intuitional resources and opportunities” (1997: 6) can provide different forms of knowledge that help adolescents navigate and succeed in the education system. Others have built on Stanton-Salazar's conceptualizations of social capital access in educational settings (Farmer-Hinton 2008; Hardie 2015, 2018; Holland 2015, 2019). Few scholars, however, have examined the role of important adults beyond those within the family and school. ${ }^{6}$

An adolescent's connection to an adult is just one part of social capital access. Adults bring embedded resources to relationships that are, perhaps, an even more critical aspect of social capital access (Castilla, Lan, and Rissing 2013; Granovetter 1973; Lin, Ensel, and Vaughn 1981; Mouw 2003). Research from the literature on labor markets underlines this point. In employment, as Pedulla and Pager (2019: 988) explain, “strategically placed social ties may provide job seekers with tacit, informal knowledge about the companies and jobs to which they are applying.” In other words, social capital access must account for both the connection itself

\footnotetext{
${ }^{6}$ Although, see work on natural or informal mentors (DuBois and Silverthorn 2005; Eby et al. 2008; Erickson, McDonald, and Elder 2009; McDonald et al. 2013). 
and the potential information and resources provided through the connection. Considering this in the context of cultural capital, the value provided by an adolescent's access to an adult is likely dependent on the adult's educational attainment. A college-educated adult is best positioned to help adolescents acquire and increase their cultural capital because they have successfully navigated the system.

\section{Social Capital Exposure}

Social capital exposure represents the time spent in a relationship that affords more opportunities to extract resources from a relationship. James Coleman (1988) conceptualized social capital as the strength of a relationship between two individuals. He examined social capital in the context of relationships between adults and adolescents. To benefit from such a relationship, adolescents must have sustained exposure and spend greater amounts of time with an adult. Following this conceptualization, the literature on social capital often examines levels of social capital between parents and children (Coleman 1987, 1988; Parcel and Dufur 2001; Sandefur, Meier, and Campbell 2006; Teachman, Paasch, and Carver 1996).

Few studies, however, directly measure social capital exposure or time in a relationship, particularly with adults other than family members. Social capital exposure can positively affect adolescents' academic achievement and reduce negative behaviors (Gaddis 2012). Multiple mechanisms may explain why social capital exposure matters, including the effort put into the relationship by both parties and the increased opportunities to model behavior and pass along knowledge. It stands to reason that social capital exposure could help adolescents acquire and increase their cultural capital. As adolescents spend more time with an adult, they have more opportunities to engage in a wider variety of activities and discussions. Social capital exposure may also provide both parties with more time to build relationship trust and broach more 
important and challenging conversations. However, in potentially building cultural capital, social capital exposure likely depends on social capital access, as a college-educated adult has the necessary knowledge and resources to help an adolescent.

\section{CONTRIBUTION AND RESEARCH QUESTIONS}

Although the literature on cultural capital is extensive, two significant gaps limit knowledge of whether cultural capital contributes to reproduction or mobility. First, most quantitative cultural capital research uses cross-sectional rather than longitudinal data. Thus, quantitative work does not provide strong causal evidence on whether disadvantaged adolescents can significantly increase their amounts of cultural capital. Second, cultural capital research focuses mostly on interactions between families and schools, without examining whether other outside adults might provide assistance. Sustained interactions with a college-educated adult from outside an adolescent's family or school may present the best opportunity for and adolescent to acquire or increase their cultural capital. In turn, if adolescents cannot acquire or increase their cultural capital, cultural capital cannot possibly result in socioeconomic mobility.

We bring together theoretical strands on social capital from literature on education, labor markets, and networks to suggest a model of cultural capital acquisition. Unlike prior work, we examine other adults who are not related to the focal adolescents and are not teachers or counselors. Additionally, we measure social capital access as both the existence of a tie to another person and that person's educational attainment. The second part of this measurement better captures the specific knowledge and resources that may be necessary to help adolescents acquire or increase their cultural capital. We also include a measure of social capital exposure to capture the opportunities to display or transfer the knowledge and resources that might increase cultural capital. Finally, we examine these processes using experimental longitudinal data that 
capture multiple measures of cultural capital at two times points. These data permit us to make causal claims about social capital access and exposure due to random assignment. The data also permit us to measure a process of cultural capital acquisition that cannot be measured with standard cross-sectional analysis.

Our analysis is guided by three research questions:

(1) Does social capital access - operationalized as random assignment to an adult mentor and that mentor's educational attainment - affect an adolescent's levels of cultural capital?

(2) Does social capital exposure - operationalized as the frequency that adolescents and mentors meet - affect an adolescent's levels of cultural capital?

(3) Are the effects of social capital access and exposure on cultural capital, if any, dependent on an adolescent's parents' educational attainment?

\section{DATA AND METHOD}

We examine our research questions using data on adolescents who participated in the Big Brothers/Big Sisters of America program (BBBSA). Adolescents were randomly assigned to either control or treatment conditions using an experimental design. Staff placed adolescents in the control condition on a waitlist and did not assign them to an adult mentor for the duration of the experiment. Staff assigned adolescents in the treatment condition to a Big Brother or Big Sister, who served as their adult mentor. We classify assignment to a mentor and that mentor's educational attainment as social capital access and the meeting frequency between adolescents and mentors as social capital exposure. Baseline and follow-up (eighteen months later) surveys recorded information on cultural capital activities and other important adolescent and family characteristics. 
We believe the BBBSA experiment represents an excellent opportunity to examine whether social capital access and exposure can help adolescents acquire or increase levels of cultural capital. As stated above, the research design and data permit us to examine the causal effects of social capital access and exposure on changes in cultural capital. Moreover, the families interested in the BBBSA program are highly motivated to help their children succeed with the assistance of other adults. In this study, parents provided various reasons why they wanted their child to interact with a Big Brother or Big Sister. The four most common reasons were: (1) providing a role model for their child (43.7\%), (2) improving their child's self-esteem (39.4\%), (3) social and cultural enrichment of their child (35.9\%), and (4) improving their child's motivation and attitude toward school (29.1\%). These reasons implicitly suggest parents hope other adults may help their children acquire cultural capital and improve their educational achievement and attainment. The sections below provide details about the sample, experimental design, variables, and analytic strategy.

\section{Sample and Experimental Design}

BBBSA program staff worked with Public/Private Ventures to implement the experimental design used in this study. Researchers took a random sample of adolescents from a sampling frame of existing BBBSA applicants waiting for an assignment to a mentor. Thus, selection into the program and the research study was voluntary. Staff members selected 1,138 adolescents for randomization into treatment and control groups. Of those randomized, 959 adolescents completed a baseline interview before treatment began and a follow-up interview eighteen months later. Of those 959, staff randomly assigned 472 adolescents to a control group and 487 to a treatment group. Adolescents in the treatment group were matched with a mentor of the same gender, but the match was randomized on other characteristics. Most importantly, 
adolescents were randomized with respect to mentor's educational attainment. Adolescents in the control group were placed back on the waiting list. They received no contact with a mentor for the entire eighteen-month study period. All data collection took place in eight cities - Columbus, Ohio; Houston, Texas; Minneapolis, Minnesota; Philadelphia, Pennsylvania; Phoenix, Arizona; Rochester, New York; San Antonio, Texas; and Wichita, Kansas.

Table 1 shows the descriptive statistics for our sample. The mean age of adolescents at the beginning of data collection in our sample is 12.3 , and the range is 9.4 to 16.7. The sample skews male (62.5\%) and has nearly as many Black adolescents (40.8\%) as White adolescents (42.3\%). It is important to note the nature of disadvantage in this sample. Although the criteria differ by chapter, the BBBSA program attempts to help the most disadvantaged children and adolescents. Nearly $83 \%$ of the sample live in households making less than $\$ 25,000$ per year, and most live in a single parent or non-parental household. This sample is skewed towards low-SES families and is not nationally representative. Importantly, however, there are no statistically significant differences on any of our control or pre-treatment variables between the three categories of social capital access (more below). Although the sample is not generalizable to all adolescents in the U.S., the experimental nature of these data allows us to examine the effects of social capital on cultural capital for disadvantaged adolescents in a causal framework absent traditional problems of selection bias (Mouw 2006).

<insert Table 1 about here>

\section{Measures of Social Capital Access and Exposure}

We operationalized our first independent variable of interest - social capital access - as access to a mentor (treatment status) and the resources embedded in that relationship (mentor's educational attainment). This operationalization closely aligns with broader definitions of social 
capital access as potential information, knowledge, other resources, and opportunities embedded within a network connection (Lin 2002, 2008; Portes 1998; Smith 2008). We trichotomized social capital access as (1) no mentor, (2) mentor with some college education (but no degree) or less, and (3) mentor with a college degree or more. Importantly, each adolescent has an equal chance of being randomly assigned to one of these three categories.

We operationalized our second independent variable of interest - social capital exposure - as the frequency that mentors and adolescents meet. Meeting frequency captures the opportunity for pairs to engage in a wider variety of activities and discussions. We dichotomized social capital exposure as (1) mentor and adolescent meet at least once per week, and (2) mentor and adolescent meet less than once per week. Although social capital exposure is not random, meeting frequency is not significantly different between mentors with less than a college degree and mentors with a college degree or greater (see Table 1).

\section{Measures of Cultural Capital}

We examine six operationalizations of cultural capital as our dependent variables of interest: weekly hours spent reading, the number of times an adolescent has visited a museum in the past 12 months, the number of times an adolescent has attended a play in the past 12 months, the average number of cultural lessons outside of school (i.e., music, art, dance, and language), the frequency that adolescents visited cultural locations in the past 18 months (e.g., library, museum, or a play), and whether adolescents stated that they learned to get along better with teachers in the past 18 months. Each of the first four cultural capital measures was recorded before treatment assignment and eighteen months later, while the last two measures were only recorded during the follow-up. 
Our first five measures of cultural capital best align with traditional quantitative operationalizations of cultural capital in the literature, although debate continues as to whether other measures could be more useful (see discussions in (Gaddis 2013; Sablan and Tierney 2014)). However, our sixth measure is closely related to operationalization of cultural capital in recent qualitative work: the concept of help-seeking behavior (Calarco 2011, 2014; Lareau 2015; Richards 2020a). Scholars suggest this is a form of cultural capital because adolescents learn that these interactions with teachers form the scaffolding of navigating the education system and lead to clear benefits within the system. Although our variable does not capture help-seeking behavior directly, learning to get along with teachers is a necessary condition for help-seeking behavior and for navigating the education system more broadly. Our multi-faceted approach to measuring cultural capital should provide a more robust examination of the effects of social capital on cultural capital.

\section{Other Variables}

The dataset contains many variables on adolescents, including the following that we use as controls: age, gender, race/ethnicity, learning disability status, and GPA at baseline.

Additionally, we use parents' highest educational attainment as either a control or interacted with social capital and exposure variables. We examine models with the latter specification to test whether social capital access and exposure affect changes in cultural capital for adolescents whose parents have a high school education or less, some college or more, or both.

\section{Analytic Strategy}

We analyze longitudinal models that include lagged dependent variables to adjust for omitted variable bias. We also include the individual-level controls listed above and city (BBBSA home chapter). We estimate a multilevel model with a random intercept for BBBSA 
home chapter due to the nested nature of the data (individuals $i$ nested within BBBSA chapters $j$ ). Presented in generalized form, the longitudinal model is:

$$
\boldsymbol{Y}_{\mathrm{ij} \text { post }}=\zeta_{\mathrm{j}}+\mu_{\mathrm{i}}+\beta_{1} \boldsymbol{S} \boldsymbol{C} \boldsymbol{A}_{\mathrm{i} j}+\beta_{2} \boldsymbol{X}_{\mathrm{ij}}+\beta_{3} \boldsymbol{Y}_{\mathrm{ij} \text { pre }}+\varepsilon_{\mathrm{ij}}
$$

where $\zeta$ is a level 2 (location) intercept, $\mu$ is a level 1 (individual) intercept, $\boldsymbol{S C A}$ is the threecategory social capital access variable, $\boldsymbol{X}$ is a vector of control variables, $\boldsymbol{Y}_{\text {pre }}$ is the lagged dependent variable, and $\varepsilon$ is the error term. We estimate separate models for each of the six cultural capital dependent variables.

Additionally, we analyze models that include (a) social capital access and exposure and (b) social capital access, exposure, and parents' highest educational attainment. To aid interpretability, we create new categorical variables that account for all possible combinations rather than create multiple interaction models. These models are essentially the same as equation 1 above, but with a different categorical variable substituted for $\boldsymbol{S C A}$.

\section{RESULTS}

Table 2 presents the effects of social capital access on each cultural capital variable. In model 1, we examine the effect of social capital access on reading habits post-treatment. The results indicate that having a mentor with less than a college degree has no significant effect on time spent reading. Having a mentor with a college degree or greater has a significant and positive effect $(\beta=0.542 ; \mathrm{p}<0.05)$ on time spent reading. In model 2 , the results indicate that having a mentor with a college degree or greater has a significant and positive effect $(\beta=0.143$; $p=0.07$ ) on museum visits. In model 3 , we find no significant effects of social capital access on play attendance. In model 4, we find that having a mentor with a college degree or greater has a significant and positive effect $(\beta=0.275 ; \mathrm{p}<0.05)$ on the number of cultural lessons. In model 5, we find that having a mentor with a college degree or greater has a significant and positive 
effect ( $\beta=0.398 ; p \leq 0.05$ ) on cultural location visits. In model 6 , we find no significant effects of social capital access on getting along better with teachers.

<insert Table 2 about here $>$

The results from Table 2 provide some moderate evidence that adolescents who have access to a highly educated adult other than their parents or teachers can increase their cultural capital. However, this relationship may vary by social capital exposure. Table 3 presents the effects of social capital access and exposure on each cultural capital variable. In model 1, we find that having a mentor with a college degree or greater has a similar effect, regardless of exposure (meets $<$ once a week: $\beta=0.574 ; \mathrm{p}=0.08$; meets $\geq$ once a week: $\beta=0.506 ; \mathrm{p}<0.05$ ). In model 4, we find that greater social capital exposure matters for the number of cultural lessons, regardless of mentor's educational attainment (mentor $\mathrm{w} /<$ college degree: $\beta=0.396$; $\mathrm{p}<0.05$; mentor $\mathrm{w} / \geq$ college degree: $\beta=0.445 ; \mathrm{p}<0.01$ ). Additionally, mentors with less than a college degree who meet less than once a week have a negative effect $(\beta=-0.656 ; \mathrm{p}<0.05)$ on the number of cultural lessons. In model 5, we find that having a mentor with a college degree or greater has a significant and positive effect $(\beta=0.851 ; p \leq 0.01)$ on cultural location visits only for those with high levels of meeting frequency. Finally, in model 6, we find that having a mentor with a college degree or greater has a significant and positive effect $(\beta=0.254 ; p \leq 0.01)$ on getting along better with teachers only for those with high levels of meeting frequency. Additionally, mentors with less than a college degree who meet less than once a week have a negative effect ( $\beta=$ $-0.367 ; \mathrm{p}=0.08$ ) on getting along better with teachers. These results clarify whether social capital access and exposure must go hand-in-hand to generate positive effects on cultural capital. Of the six significant positive effects, four were due to both high levels of access and high levels of exposure. 
<insert Table 3 about here>

$<$ insert Table 4 about here $>$

Table 4 presents the effects of social capital access and exposure by parents' educational attainment on each cultural capital variable. This table presents only the eight categories of this combined variable (with "no mentor" as the reference category) and suppresses all other controls for brevity and readability. The models show numerous positive and negative effects of this combined variable on cultural capital. Thus, in Figure 1, we display only statistically significant effects ( $\mathrm{p}<0.05)$ to visually depict these patterns across categories.

<insert Figure 1 about here>

We find only negative effects of social capital access and exposure on cultural capital for adolescents with a parent with low educational attainment. However, we find mostly positive effects of social capital access and exposure on cultural capital for adolescents with a parent with high educational attainment. Four of the seven (57.1\%) positive and statistically significant effects occur in one scenario: high levels of social capital access and high levels of social capital exposure. Additionally, six of the seven (85.7\%) positive and statistically significant effects occur when levels of social capital exposure are high. In the case of two cultural capital variables (museum visits and get along better with teachers), the effects are not dependent on mentor's education level. In other words, having a mentor who meets frequency matters, but the effects are similar between mentors with less than a college degree and mentors with a college degree or greater. Overall, these results suggest two important points. First, the positive effects of social capital access and exposure only apply to adolescents with a parent with high educational attainment. Second, both social capital access and exposure are important. However, a mentor's 
educational attainment appears to be less important than how often adolescents meet with mentors.

\section{DISCUSSION}

Across a vast literature in education, scholars have examined the influence of cultural capital in educational achievement and attainment and debated whether cultural capital contributes to socioeconomic reproduction or mobility. The existing literature has two important limitations that muddle our understanding of these processes. First, research focuses only on cross-sectional associations and is unclear about whether or how disadvantaged adolescents can increase their amounts of cultural capital. Second, most research examines cultural capital only as a process that occurs between families and schools. In this research, we addressed those gaps by merging theories of social capital from the literatures on education, employment, and networks. We created a framework that suggests adolescents might form relationships with unrelated adults who are not teachers or school counselors to acquire or increase their cultural capital. Furthermore, we proffered that relationships with college-educated adults (social capital access) who engage in frequent interaction with adolescents (social capital exposure) might most effectively increase adolescents' cultural capital.

We found that most of the positive effects of social capital on cultural capital occurred among adolescents whose mentors were college-educated and when adolescents and mentors met frequently. Furthermore, we found that these effects only held for adolescents whose parents had some college experience. These findings have important implications for research on education, inequality, and cultural capital more broadly. We believe this work represents the strongest evidence to date that cultural capital serves to maintain a system of socioeconomic reproduction rather than mobility. These findings strongly support the mostly qualitative work that suggests 
the same reproduction process of cultural capital. These results are disappointing for scholars of inequality and policymakers who hope programs like BBBSA might bridge cultural capital gaps and increase college-going among disadvantaged students. Our research does not suggest that programs and policies cannot increase cultural capital among disadvantaged adolescents. Still, it does seem likely that a program would have to be designed with that express purpose. Additionally, our research does not suggest that the BBBSA program is ineffective. Other scholars have found many positive effects of the program for students from all backgrounds (e.g., (Gaddis 2012). Still, more work is needed to examine whether other programs or other contexts might provide more effective means to increase the cultural capital of adolescents with non-college-educated parents.

It is a bit of a puzzle why these forms of social capital only led to positive effects on cultural capital for adolescents whose parents had at least some college experience. Mentors with a college degree may focus more on academic activities and discussions during their time with adolescents. They may specifically use their time to engage with adolescents in activities that increase cultural capital (e.g., attending museums and visiting cultural locations). Alternatively, they may use their knowledge and clout with parents to convince them to engage in similar activities with their children and provide information on the importance of these activities. However, it is unclear why mentors with college degrees would not be able to do the same for adolescents whose parents did not attend college. Perhaps these positive effects on cultural capital only arise when parents and mentors share similar beliefs about what adolescents need from the relationship. Moreover, low-SES parents may not be able to commit the time, transportation, and financial resources that cultural capital activities require, even if an outside 
adult encourages them. Future work should investigate this part of the social capital to cultural capital link in more detail.

Our analysis used experimental data from the BBBSA mentoring program. These data have some limitations (i.e., moderate sample size and relative disadvantage in the sample). Still, we believe the experimental nature of the data collection provides a unique opportunity that counterbalances these limitations. Although parents select into the BBBSA program, random assignment to treatment or control conditions and random assignment to specific mentors provide strong causal evidence of the effects of social capital access and exposure on cultural capital. Moreover, the longitudinal research design provided us with an opportunity to measure changes in cultural capital directly. This form of cultural capital analysis is scarce, despite thousands of articles on the topic. Finally, the motivation of parents seeking out this program should have essentially stacked the deck in favor of finding at least some small positive effects of cultural capital suggesting a socioeconomic mobility process. Still, we found no such evidence. Unfortunately, the value of this type of social capital access and exposure in increasing cultural capital is limited to more advantaged families.

We believe that five of our cultural capital measures are well-aligned with prior quantitative work, and our sixth measure (i.e., "get along better with teachers") is closer to what qualitative work measures. Additionally, the first five measures are activities that mentors can directly participate in with adolescents, but the sixth measure requires passing along knowledge that the adolescent must apply herself. Some researchers have questioned the appropriateness of these traditional quantitative measures (Davies and Rizk 2018). Research, however, finds that these measures predict educational achievement and attainment, likely because they help spark intellectual curiosity, knowledge acquisition, and a greater engagement with education. 
Our work also suggests that future research should be aware of a slight but essential distinction among three interrelated concepts. Scholars have not clearly defined conceptual boundaries between adolescents' help-seeking behavior, teachers and counselors as sources of social capital, and non-educational actors as sources of social capital. This distinction is crucial because help-seeking behavior can be seen as cultural capital but may also be translated into social capital through interactions with teachers and/or counselors. Moreover, different sources of social capital (i.e., teachers and counselors versus other non-school affiliated adults) may provide further value to adolescents due to the gatekeeper role. Future research should examine this possibility.

Additional broad questions remain that we were unable to address in our research. First, as discussed above, what specific mechanisms lead adolescents to increase cultural capital through social capital access and exposure? Second, are there other ways to attain or increase cultural capital, not just via different forms of social capital, but more broadly? Third, evidence suggests that race and ethnicity are often paramount in understanding the value of cultural capital, so how do race and ethnicity shape the process of cultural capital acquisition (Richards 2020b)? These questions will provide salient details about cultural capital acquisition that may further clarify the social mobility versus reproduction debate.

Our findings are theoretically and empirically interesting but discouraging because they suggest social capital access and exposure may not be a route for disadvantaged adolescents to acquire or increase cultural capital. These results give credence to the thesis that cultural capital may only work as an engine of social reproduction if disadvantaged students cannot easily or systematically acquire or increase cultural capital. If so, ideas and policies to reduce educational 
inequality may need to focus more on changing the attitudes and behaviors of institutional gatekeepers rather than disadvantaged families. 
Table 1. Descriptive Statistics

\begin{tabular}{|c|c|c|c|c|}
\hline & \multicolumn{4}{|c|}{ Mean / Proportion } \\
\hline & \multirow[t]{2}{*}{$\underline{\text { Total }}$} & \multicolumn{3}{|c|}{$\underline{\text { Social Capital Access }}$} \\
\hline & & No mentor & $\begin{array}{c}\text { Mentor } \\
\text { w/ < col. } \\
\text { deg. }\end{array}$ & $\begin{array}{c}\text { Mentor } \\
\text { w/ } \geq \text { col. } \\
\text { deg. }\end{array}$ \\
\hline \multicolumn{5}{|l|}{ Controls } \\
\hline Age & 12.25 & 12.33 & 12.04 & 12.17 \\
\hline Male & 0.625 & 0.650 & 0.534 & 0.617 \\
\hline White & 0.423 & 0.398 & 0.486 & 0.448 \\
\hline Black & 0.408 & 0.417 & 0.370 & 0.409 \\
\hline Hispanic & 0.103 & 0.113 & 0.082 & 0.091 \\
\hline Other Race/Ethnicity & 0.066 & 0.072 & 0.061 & 0.052 \\
\hline Parent $\leq$ high school & 0.582 & 0.587 & 0.589 & 0.565 \\
\hline Parent $\geq$ some college & 0.418 & 0.413 & 0.411 & 0.435 \\
\hline Learning disability & 0.155 & 0.161 & 0.151 & 0.143 \\
\hline GPA (pre-treatment) & 2.77 & 2.77 & 2.67 & 2.83 \\
\hline \multicolumn{5}{|l|}{ Cultural Capital (pre-treatment) } \\
\hline Time spent reading & 2.12 & 2.07 & 2.10 & 2.24 \\
\hline Museum visits & 1.03 & 0.97 & 0.91 & 1.25 \\
\hline Play attendance & 0.98 & 0.99 & 0.78 & 1.08 \\
\hline Cultural lessons & 0.37 & 0.35 & 0.42 & 0.38 \\
\hline \multicolumn{5}{|l|}{ Social Capital Exposure } \\
\hline Meeting Frequency < once a week & & & 0.500 & 0.558 \\
\hline Meeting Frequency $\geq$ once a week & & & 0.500 & 0.442 \\
\hline
\end{tabular}


Table 2. Social Capital Access Models Predicting Cultural Capital

\begin{tabular}{|c|c|c|c|c|c|c|}
\hline & $\begin{array}{c}(1) \\
\text { Time Spent } \\
\text { Reading }\end{array}$ & $\begin{array}{c}(2) \\
\text { Museum } \\
\text { Visits }\end{array}$ & $\begin{array}{c}\text { (3) } \\
\text { Play } \\
\text { Attendance }\end{array}$ & $\begin{array}{c}\text { (4) } \\
\text { Cultural } \\
\text { Lessons }\end{array}$ & $\begin{array}{c}\text { (5) } \\
\text { Cultural } \\
\text { Location } \\
\text { Visits }\end{array}$ & $\begin{array}{c}\text { (6) } \\
\text { Get Along } \\
\text { Better w/ } \\
\text { Teachers }\end{array}$ \\
\hline \multicolumn{7}{|l|}{ Controls } \\
\hline Male & $\begin{array}{l}-0.525^{*} \\
(0.171)\end{array}$ & $\begin{array}{l}-0.017 \\
(0.077)\end{array}$ & $\begin{array}{l}-0.183^{*} \\
(0.077)\end{array}$ & $\begin{array}{l}-0.317^{* *} \\
(0.112)\end{array}$ & $\begin{array}{l}-0.522^{* *} \\
(0.184)\end{array}$ & $\begin{array}{c}0.148 \\
(0.157)\end{array}$ \\
\hline $\begin{array}{l}\text { Race: Black } \\
\text { (ref: White) }\end{array}$ & $\begin{array}{l}-0.541^{*} \\
(0.196)\end{array}$ & $\begin{array}{l}-0.321^{* * *} \\
(0.081)\end{array}$ & $\begin{array}{c}0.065 \\
(0.084)\end{array}$ & $\begin{array}{l}0.306^{* *} \\
(0.116)\end{array}$ & $\begin{array}{l}0.451^{*} \\
(0.190)\end{array}$ & $\begin{array}{l}0.374^{+} \\
(0.220)\end{array}$ \\
\hline Race: Hispanic & $\begin{array}{l}-0.730 \\
(0.427)\end{array}$ & $\begin{array}{c}0.155 \\
(0.120)\end{array}$ & $\begin{array}{l}0.395^{* *} \\
(0.126)\end{array}$ & $\begin{array}{l}-0.089 \\
(0.208)\end{array}$ & $\begin{array}{c}0.323 \\
(0.324)\end{array}$ & $\begin{array}{c}0.133 \\
(0.228)\end{array}$ \\
\hline Race: Other & $\begin{array}{l}-0.206 \\
(0.353)\end{array}$ & $\begin{array}{l}-0.080 \\
(0.141)\end{array}$ & $\begin{array}{c}0.146 \\
(0.144)\end{array}$ & $\begin{array}{l}-0.924^{* *} \\
(0.345)\end{array}$ & $\begin{array}{l}0.621^{+} \\
(0.368)\end{array}$ & $\begin{array}{c}0.370 \\
(0.404)\end{array}$ \\
\hline Parent $\geq$ some college & $\begin{array}{l}0.545^{* *} \\
(0.137)\end{array}$ & $\begin{array}{l}0.197^{* *} \\
(0.072)\end{array}$ & $\begin{array}{l}0.173^{*} \\
(0.075)\end{array}$ & $\begin{array}{l}-0.076 \\
(0.109)\end{array}$ & $\begin{array}{c}0.140 \\
(0.177)\end{array}$ & $\begin{array}{c}0.043 \\
(0.295)\end{array}$ \\
\hline GPA (pre-treatment) & $\begin{array}{c}0.043 \\
(0.103)\end{array}$ & $\begin{array}{l}0.093^{*} \\
(0.046)\end{array}$ & $\begin{array}{l}0.104^{*} \\
(0.048)\end{array}$ & $\begin{array}{l}0.141^{*} \\
(0.071)\end{array}$ & $\begin{array}{c}0.150 \\
(0.106)\end{array}$ & $\begin{array}{c}0.043 \\
(0.143)\end{array}$ \\
\hline $\begin{array}{l}\text { Cultural capital (y } \\
\text { variable pre-treatment) }\end{array}$ & $\begin{array}{l}0.169^{*} \\
(0.055)\end{array}$ & $\begin{array}{l}0.139^{* * *} \\
(0.023)\end{array}$ & $\begin{array}{l}0.094^{* * *} \\
(0.021)\end{array}$ & $\begin{array}{l}0.213^{* * *} \\
(0.031)\end{array}$ & & \\
\hline \multicolumn{7}{|c|}{ Social Capital Access (ref: No mentor) } \\
\hline Mentor w/ < col. deg. & $\begin{array}{c}-0.021 \\
(0.271)\end{array}$ & $\begin{array}{c}0.001 \\
(0.104)\end{array}$ & $\begin{array}{c}0.050 \\
(0.104)\end{array}$ & $\begin{array}{c}-0.062 \\
(0.157)\end{array}$ & $\begin{array}{c}0.187 \\
(0.228)\end{array}$ & $\begin{array}{c}-0.148 \\
(0.149)\end{array}$ \\
\hline Mentor w/ $\geq$ col. deg. & $\begin{array}{c}0.542^{*} \\
(0.217)\end{array}$ & $\begin{array}{c}0.143^{+} \\
(0.080)\end{array}$ & $\begin{array}{l}-0.093 \\
(0.090)\end{array}$ & $\begin{array}{c}0.275^{*} \\
(0.118)\end{array}$ & $\begin{array}{l}0.398^{*} \\
(0.192)\end{array}$ & $\begin{array}{c}0.195 \\
(0.157)\end{array}$ \\
\hline Constant & $\begin{array}{c}0.897 \\
(0.898)\end{array}$ & $\begin{array}{c}0.757^{+} \\
(0.412)\end{array}$ & $\begin{array}{l}-0.095 \\
(0.417)\end{array}$ & $\begin{array}{l}-1.289^{*} \\
(0.601)\end{array}$ & $\begin{array}{c}0.488 \\
(0.957)\end{array}$ & $\begin{array}{c}-0.264 \\
(0.459)\end{array}$ \\
\hline Observations & 959 & 959 & 959 & 959 & 959 & 959 \\
\hline
\end{tabular}

Note: Each model also controls for age, learning disability, and location (city). Model 1: linear regression. Models 2, 3, \& 4: Poisson regression. Models 5 \& 6: logistic regression. Standard errors in parentheses.

${ }^{+} p<0.10,{ }^{*} p<0.05,{ }^{* *} p<0.01,{ }^{* * *} p<0.001$ 
Table 3. Social Capital Access and Exposure Models Predicting Cultural Capital

\begin{tabular}{|c|c|c|c|c|c|c|}
\hline & $\begin{array}{c}(1) \\
\text { Time Spent } \\
\text { Reading }\end{array}$ & $\begin{array}{c}(2) \\
\text { Museum } \\
\text { Visits }\end{array}$ & $\begin{array}{c}\text { (3) } \\
\text { Play } \\
\text { Attendance }\end{array}$ & $\begin{array}{c}(4) \\
\text { Cultural } \\
\text { Lessons }\end{array}$ & $\begin{array}{c}(5) \\
\text { Cultural } \\
\text { Location } \\
\text { Visits }\end{array}$ & $\begin{array}{c}(6) \\
\text { Get Along } \\
\text { Better w/ } \\
\text { Teachers }\end{array}$ \\
\hline \multicolumn{7}{|l|}{ Controls } \\
\hline Male & $\begin{array}{l}-0.517^{*} \\
(0.164)\end{array}$ & $\begin{array}{l}-0.017 \\
(0.077)\end{array}$ & $\begin{array}{l}-0.182^{*} \\
(0.077)\end{array}$ & $\begin{array}{l}-0.328^{* *} \\
(0.111)\end{array}$ & $\begin{array}{l}-0.522^{* *} \\
(0.185)\end{array}$ & $\begin{array}{c}0.139 \\
(0.153)\end{array}$ \\
\hline $\begin{array}{l}\text { Race: Black } \\
\text { (ref: White) }\end{array}$ & $\begin{array}{l}-0.554^{*} \\
(0.188)\end{array}$ & $\begin{array}{l}-0.321^{* * *} \\
(0.081)\end{array}$ & $\begin{array}{c}0.059 \\
(0.084)\end{array}$ & $\begin{array}{l}0.342^{* *} \\
(0.116)\end{array}$ & $\begin{array}{l}0.487^{*} \\
(0.192)\end{array}$ & $\begin{array}{l}0.392^{+} \\
(0.220)\end{array}$ \\
\hline Race: Hispanic & $\begin{array}{l}-0.748 \\
(0.414)\end{array}$ & $\begin{array}{c}0.155 \\
(0.120)\end{array}$ & $\begin{array}{l}0.386^{* *} \\
(0.127)\end{array}$ & $\begin{array}{l}-0.042 \\
(0.209)\end{array}$ & $\begin{array}{c}0.370 \\
(0.326)\end{array}$ & $\begin{array}{c}0.152 \\
(0.217)\end{array}$ \\
\hline Race: Other & $\begin{array}{l}-0.243 \\
(0.337)\end{array}$ & $\begin{array}{l}-0.084 \\
(0.141)\end{array}$ & $\begin{array}{c}0.135 \\
(0.146)\end{array}$ & $\begin{array}{l}-0.858^{*} \\
(0.345)\end{array}$ & $\begin{array}{l}0.639^{+} \\
(0.373)\end{array}$ & $\begin{array}{c}0.405 \\
(0.400)\end{array}$ \\
\hline Parent $\geq$ some college & $\begin{array}{l}0.545^{* *} \\
(0.131)\end{array}$ & $\begin{array}{l}0.198^{* *} \\
(0.072)\end{array}$ & $\begin{array}{l}0.172^{*} \\
(0.075)\end{array}$ & $\begin{array}{l}-0.068 \\
(0.109)\end{array}$ & $\begin{array}{c}0.144 \\
(0.178)\end{array}$ & $\begin{array}{c}0.046 \\
(0.295)\end{array}$ \\
\hline GPA (pre-treatment) & $\begin{array}{c}0.045 \\
(0.106)\end{array}$ & $\begin{array}{l}0.094^{*} \\
(0.046)\end{array}$ & $\begin{array}{l}0.105^{*} \\
(0.048)\end{array}$ & $\begin{array}{l}0.140^{*} \\
(0.071)\end{array}$ & $\begin{array}{c}0.159 \\
(0.107)\end{array}$ & $\begin{array}{c}0.039 \\
(0.140)\end{array}$ \\
\hline $\begin{array}{l}\text { Cultural capital (y } \\
\text { variable pre-treatment) }\end{array}$ & $\begin{array}{l}0.170^{*} \\
(0.054)\end{array}$ & $\begin{array}{l}0.139^{* * *} \\
(0.023)\end{array}$ & $\begin{array}{l}0.094^{* * *} \\
(0.021)\end{array}$ & $\begin{array}{l}0.211^{* * *} \\
(0.031)\end{array}$ & & \\
\hline \multicolumn{7}{|c|}{ Social Capital Access and Exposure (ref: No mentor) } \\
\hline $\begin{array}{l}\text { Mentor w/ < col. deg. } \\
\text { meets < once a week }\end{array}$ & $\begin{array}{c}0.320 \\
(0.313)\end{array}$ & $\begin{array}{c}0.026 \\
(0.140)\end{array}$ & $\begin{array}{c}0.153 \\
(0.130)\end{array}$ & $\begin{array}{l}-0.656^{*} \\
(0.262)\end{array}$ & $\begin{array}{c}0.045 \\
(0.287)\end{array}$ & $\begin{array}{l}-0.367^{+} \\
(0.209)\end{array}$ \\
\hline $\begin{array}{l}\text { Mentor w/ < col. deg. } \\
\text { meets } \geq \text { once a week }\end{array}$ & $\begin{array}{l}-0.416 \\
(0.291)\end{array}$ & $\begin{array}{l}-0.025 \\
(0.141)\end{array}$ & $\begin{array}{l}-0.082 \\
(0.152)\end{array}$ & $\begin{array}{l}0.396^{*} \\
(0.186)\end{array}$ & $\begin{array}{c}0.361 \\
(0.303)\end{array}$ & $\begin{array}{c}0.117 \\
(0.384)\end{array}$ \\
\hline $\begin{array}{l}\text { Mentor } \mathrm{w} / \geq \text { col. deg. } \\
\text { meets < once a week }\end{array}$ & $\begin{array}{l}0.574^{+} \\
(0.286)\end{array}$ & $\begin{array}{c}0.129 \\
(0.104)\end{array}$ & $\begin{array}{l}-0.063 \\
(0.114)\end{array}$ & $\begin{array}{c}0.134 \\
(0.151)\end{array}$ & $\begin{array}{c}0.047 \\
(0.237)\end{array}$ & $\begin{array}{c}0.146 \\
(0.163)\end{array}$ \\
\hline $\begin{array}{l}\text { Mentor } \mathrm{w} / \geq \text { col. deg. } \\
\text { meets } \geq \text { once a week }\end{array}$ & $\begin{array}{l}0.506^{*} \\
(0.198)\end{array}$ & $\begin{array}{c}0.160 \\
(0.110)\end{array}$ & $\begin{array}{l}-0.128 \\
(0.129)\end{array}$ & $\begin{array}{l}0.445^{* *} \\
(0.157)\end{array}$ & $\begin{array}{l}0.851^{* *} \\
(0.258)\end{array}$ & $\begin{array}{l}0.254^{* *} \\
(0.093)\end{array}$ \\
\hline Constant & $\begin{array}{c}0.886 \\
(0.856)\end{array}$ & $\begin{array}{l}0.762^{+} \\
(0.413)\end{array}$ & $\begin{array}{l}-0.093 \\
(0.417)\end{array}$ & $\begin{array}{l}-1.281^{*} \\
(0.602)\end{array}$ & $\begin{array}{c}0.548 \\
(0.963)\end{array}$ & $\begin{array}{l}-0.278 \\
(0.463)\end{array}$ \\
\hline Observations & 959 & 959 & 959 & 959 & 959 & 959 \\
\hline
\end{tabular}

Note: Each model also controls for age, learning disability, and location (city). Model 1: linear regression. Models 2, 3, \& 4: Poisson regression. Models 5 \& 6: logistic regression. Standard errors in parentheses.

${ }^{+} p<0.10,{ }^{*} p<0.05,{ }^{* *} p<0.01,{ }^{* * *} p<0.001$ 
Table 4. Social Capital Access, Exposure, and Parental Education Models Predicting Cultural Capital

\begin{tabular}{|c|c|c|c|c|c|c|}
\hline & (1) & (2) & (3) & (4) & (5) & (6) \\
\hline & $\begin{array}{l}\text { Time Spent } \\
\text { Reading }\end{array}$ & Museum Visits & $\begin{array}{c}\text { Play } \\
\text { Attendance }\end{array}$ & $\begin{array}{l}\text { Cultural } \\
\text { Lessons }\end{array}$ & $\begin{array}{c}\text { Cultural } \\
\text { Location } \\
\text { Visits } \\
\end{array}$ & $\begin{array}{c}\text { Get Along } \\
\text { Better w/ } \\
\text { Teachers }\end{array}$ \\
\hline Mentor w/ < col. deg. & 0.516 & 0.104 & 0.128 & $-0.165^{*}$ & -0.001 & -0.101 \\
\hline $\begin{array}{l}\& \text { Parent }<\text { some college } \\
\& \text { meets }<\text { once a week }\end{array}$ & $(0.412)$ & $(0.155)$ & $(0.147)$ & $(0.067)$ & $(0.073)$ & $(0.120)$ \\
\hline Mentor w/ < col. deg. & $-0.757^{+}$ & $-0.340^{* *}$ & -0.060 & 0.187 & 0.066 & -0.074 \\
\hline $\begin{array}{l}\& \text { Parent }<\text { some college } \\
\& \text { meets } \geq \text { once a week }\end{array}$ & $(0.375)$ & $(0.118)$ & $(0.142)$ & $(0.123)$ & $(0.085)$ & $(0.105)$ \\
\hline Mentor w/ < col. deg & -0.014 & -0.137 & 0.131 & $-0.198^{*}$ & 0.023 & -0.071 \\
\hline $\begin{array}{l}\& \text { Parent } \geq \text { some college } \\
\& \text { meets }<\text { once a week }\end{array}$ & $(0.356)$ & $(0.171)$ & (0.189) & $(0.080)$ & $(0.090)$ & $(0.132)$ \\
\hline Mentor w/ < col. deg & 0.018 & $0.397^{*}$ & -0.081 & 0.180 & 0.101 & $0.173^{*}$ \\
\hline $\begin{array}{l}\& \text { Parent } \geq \text { some college } \\
\& \text { meets } \geq \text { once a week }\end{array}$ & $(0.495)$ & $(0.172)$ & $(0.173)$ & $(0.151)$ & $(0.098)$ & $(0.085)$ \\
\hline Mentor $\mathrm{w} / \geq$ col. deg. & 0.292 & 0.030 & -0.066 & -0.047 & -0.022 & 0.084 \\
\hline $\begin{array}{l}\& \text { Parent }<\text { some college } \\
\& \text { meets }<\text { once a week }\end{array}$ & $(0.481)$ & $(0.119)$ & $(0.109)$ & $(0.069)$ & $(0.059)$ & $(0.076)$ \\
\hline Mentor w/ $\geq$ col. deg. & 0.394 & -0.108 & $-0.309^{* *}$ & 0.095 & 0.100 & -0.066 \\
\hline $\begin{array}{l}\text { \& Parent }<\text { some college } \\
\& \text { meets } \geq \text { once a week }\end{array}$ & $(0.361)$ & $(0.120)$ & $(0.101)$ & $(0.098)$ & $(0.075)$ & $(0.059)$ \\
\hline Mentor w/ $\geq$ col. deg & $0.998^{* *}$ & 0.224 & -0.018 & $0.180^{+}$ & 0.054 & -0.035 \\
\hline $\begin{array}{l}\& \text { Parent } \geq \text { some college } \\
\& \text { meets }<\text { once a week }\end{array}$ & $(0.189)$ & $(0.143)$ & $(0.128)$ & $(0.101)$ & $(0.070)$ & $(0.086)$ \\
\hline Mentor w/ $\geq$ col. deg & 0.671 & $0.458^{* *}$ & 0.190 & $0.358^{*}$ & $0.309^{* *}$ & $0.210^{* *}$ \\
\hline $\begin{array}{l}\& \text { Parent } \geq \text { some college } \\
\& \text { meets } \geq \text { once a week }\end{array}$ & $(0.395)$ & $(0.172)$ & $(0.159)$ & $(0.141)$ & $(0.078)$ & $(0.073)$ \\
\hline
\end{tabular}

Note: Each model also controls for gender, race, GPA (pre-treatment), cultural capital (y variable pre-treatment), age, learning disability, and location (city). Model 1: linear regression. Models 2, 3, \& 4: Poisson regression. Models 5 \& 6: logistic regression. Standard errors in parentheses.

${ }^{+} p<0.10,{ }^{*} p<0.05,{ }^{* *} p<0.01,{ }^{* * *} p<0.001$ 


\section{Figure 1. Coefficient Plots from Social Capital Access, Exposure, and Parental Education Models Predicting Cultural Capital}

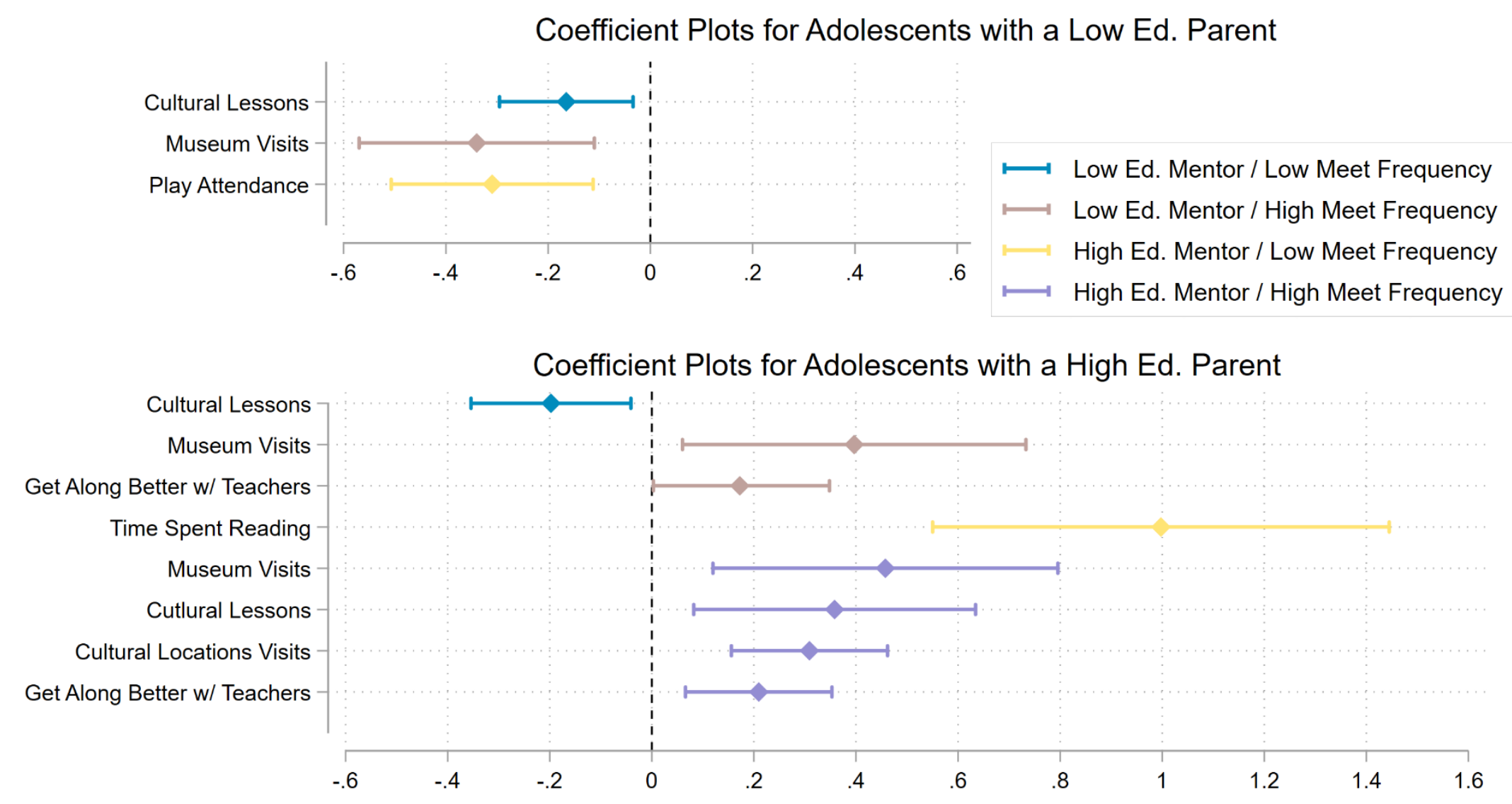

Note: This figure shows only the statistically significant $(\mathrm{p}<0.05)$ coefficients from six regression models (one for each dependent variable). Each model includes all controls shown in Table 4 and a categorical variable with nine possible values $-(0)$ reference: no mentor, $(1)$ parent $<$ some college / mentor $<$ college degree / meet < once a week, (2) parent $<$ some college / mentor < college degree / meet $\geq$ once a week, (3) parent $<$ some college / mentor $\geq$ college degree / meet < once a week, (4) parent < some college / mentor $\geq$ college degree / meet $\geq$ once a week, (5) parent $\geq$ some college / mentor $<$ college degree / meet $<$ once a week, (6) parent $\geq$ some college / mentor $<$ college degree / meet $\geq$ once a week, (7) parent $\geq$ some college / mentor $\geq$ college degree / meet $<$ once a week, (8) parent $\geq$ some college / mentor $\geq$ college degree / meet $\geq$ once a week. 


\section{REFERENCES}

Aries, Elizabeth. 2008. Race and Class Matters at an Elite College. Temple University Press.

Armstrong, Elizabeth A., and Laura T. Hamilton. 2013. Paying for the Party: How College Maintains Inequality. Harvard University Press.

Aschaffenburg, Karen, and Ineke Maas. 1997. "Cultural and Educational Careers: The Dynamics of Social Reproduction.” American Sociological Review 62(4):573-87. doi: 10.2307/2657427.

Bourdieu, Pierre. 1984. Distinction: A Social Critique of the Judgement of Taste. Harvard University Press.

Bourdieu, Pierre. 1986. “The Forms of Capital.” Pp. 105-15 in Education, Globalization, and Social Change, edited by H. Lauder, P. Brown, J.-A. Dillabough, and A. H. Halsey. Oxford, England: Oxford University Press.

Bourdieu, Pierre, and Jean-Claude Passeron. 1977. Reproduction in Education, Society, and Culture. London, UK: SAGE Publications, Inc.

Breinholt, Asta, and Mads Meier Jæger. 2020. "How Does Cultural Capital Affect Educational Performance: Signals or Skills?” The British Journal of Sociology 71(1):28-46. doi: https://doi.org/10.1111/1468-4446.12711.

Broh, Beckett A. 2002. "Linking Extracurricular Programming to Academic Achievement: Who Benefits and Why?” Sociology of Education 75(1):69-95. doi: 10.2307/3090254.

Calarco, Jessica McCrory. 2011. “'I Need Help!’ Social Class and Children’s Help-Seeking in Elementary School.” American Sociological Review 76(6):862-82. doi:

$10.1177 / 0003122411427177$.

Calarco, Jessica McCrory. 2014. “Coached for the Classroom: Parents’ Cultural Transmission and Children’s Reproduction of Educational Inequalities.” American Sociological Review 79(5):1015-37. doi: 10.1177/0003122414546931.

Calarco, Jessica McCrory. 2018. Negotiating Opportunities: How the Middle Class Secures Advantages in School. Oxford University Press.

Carbonaro, William J. 1998. “A Little Help from My Friend’s Parents: Intergenerational Closure and Educational Outcomes.” Sociology of Education 71(4):295-313. doi: 10.2307/2673172.

Castilla, Emilio J., George J. Lan, and Ben A. Rissing. 2013. “Social Networks and Employment: Outcomes (Part 2).” Sociology Compass 7(12):1013-26. doi: 10.1111/soc4.12095.

Cherng, Hua-Yu Sebastian, Jessica McCrory Calarco, and Grace Kao. 2013. “Along for the Ride Best Friends' Resources and Adolescents' College Completion.” American Educational Research Journal 50(1):76-106. doi: 10.3102/0002831212466689.

Coleman, James S. 1987. “Families and Schools.” Educational Researcher 16(6):32-38. doi: 10.3102/0013189X016006032. 
Coleman, James S. 1988. "Social Capital in the Creation of Human Capital.” American Journal of Sociology 94:S95-120.

Coleman, James S. 1994. Foundations of Social Theory. Harvard University Press.

Covay, Elizabeth, and William Carbonaro. 2010. “After the Bell: Participation in Extracurricular Activities, Classroom Behavior, and Academic Achievement.” Sociology of Education 83(1):2045. doi: 10.1177/0038040709356565.

Davies, Scott, and Jessica Rizk. 2018. "The Three Generations of Cultural Capital Research: A Narrative Review.” Review of Educational Research 88(3):331-65. doi: 10.3102/0034654317748423.

De Graaf, Nan Dirk, Paul M. De Graaf, and Gerbert Kraaykamp. 2000. "Parental Cultural Capital and Educational Attainment in the Netherlands: A Refinement of the Cultural Capital Perspective.” Sociology of Education 73(2):92-111. doi: 10.2307/2673239.

Dika, Sandra L., and Kusum Singh. 2002. "Applications of Social Capital in Educational Literature: A Critical Synthesis.” Review of Educational Research 72(1):31-60.

DiMaggio, Paul. 1982. "Cultural Capital and School Success: The Impact of Status Culture Participation on the Grades of U.S. High School Students.” American Sociological Review 47(2):189-201. doi: $10.2307 / 2094962$.

Dimaggio, Paul, and John Mohr. 1996. “The Intergenerational Transmission of Cultural Capital.” Research on Social Stratification and Mobility 167-99.

DuBois, David L., and Naida Silverthorn. 2005. "Natural Mentoring Relationships and Adolescent Health: Evidence From a National Study.” American Journal of Public Health 95(3):518-24. doi: 10.2105/AJPH.2003.031476.

Dumais, Susan A. 2008. "Adolescents' Time Use and Academic Achievement: A Test of the Reproduction and Mobility Models*.” Social Science Quarterly 89(4):867-86. doi: https://doi.org/10.1111/j.1540-6237.2008.00588.x.

Dumais, Susan A., Richard J. Kessinger, and Bonny Ghosh. 2012. “Concerted Cultivation and Teachers' Evaluations of Students: Exploring the Intersection of Race and Parents' Educational Attainment.” Sociological Perspectives 55(1):17-42. doi: 10.1525/sop.2012.55.1.17.

Dumais, Susan A., and Aaryn Ward. 2010. “Cultural Capital and First-Generation College Success.” Poetics 38(3):245-65. doi: 10.1016/j.poetic.2009.11.011.

Eby, Lillian T., Tammy D. Allen, Sarah C. Evans, Thomas Ng, and David L. DuBois. 2008. “Does Mentoring Matter? A Multidisciplinary Meta-Analysis Comparing Mentored and Non-Mentored Individuals.” Journal of Vocational Behavior 72(2):254-67. doi: 10.1016/j.jvb.2007.04.005.

Erickson, Lance D., Steve McDonald, and Glen H. Elder. 2009. "Informal Mentors and Education: Complementary or Compensatory Resources?” Sociology of Education 82(4):344-67. doi: 10.1177/003804070908200403.

Farkas, George. 2017. Human Capital or Cultural Capital?: Ethnicity and Poverty Groups in an Urban School District. 2nd ed. Routledge. 
Farkas, George, Robert P. Grobe, Daniel Sheehan, and Yuan Shuan. 1990. “Cultural Resources and School Success: Gender, Ethnicity, and Poverty Groups within an Urban School District.” American Sociological Review 55(1):127-42. doi: 10.2307/2095708.

Farmer-Hinton, Raquel L. 2008. "Social Capital and College Planning: Students of Color Using School Networks for Support and Guidance.” Education and Urban Society 41(1):127-57. doi: $10.1177 / 0013124508321373$.

Gaddis, S. Michael. 2012. "What's in a Relationship? An Examination of Social Capital, Race and Class in Mentoring Relationships.” Social Forces 90(4):1237-69. doi: 10.1093/sf/sos003.

Gaddis, S. Michael. 2013. "The Influence of Habitus in the Relationship between Cultural Capital and Academic Achievement.” Social Science Research 42(1):1-13. doi: 10.1016/j.ssresearch.2012.08.002.

Gaddis, S. Michael. 2015. "Discrimination in the Credential Society: An Audit Study of Race and College Selectivity in the Labor Market.” Social Forces 93(4):1451-79. doi: 10.1093/sf/sou111.

Granovetter, Mark S. 1973. “The Strength of Weak Ties.” American Journal of Sociology 78(6):1360-80.

Greene, Jay P., Heidi H. Erickson, Angela R. Watson, and Molly I. Beck. 2018. “The Play’s the Thing: Experimentally Examining the Social and Cognitive Effects of School Field Trips to Live Theater Performances.” Educational Researcher 47(4):246-54. doi: 10.3102/0013189X18761034.

Hardie, Jessica Halliday. 2015. "The Best Laid Plans: Social Capital in the Development of Girls' Educational and Occupational Plans.” Social Problems 62(2):241-65. doi: 10.1093/socpro/spv003.

Hardie, Jessica Halliday. 2018. "Rethinking School-Based Ties: Social Class and the Role of Institutional Agents in Adolescents’ College Plans.” Teachers College Record 120:1-49.

Hofferth, Sandra L., Johanne Boisjoly, and Greg J. Duncan. 1998. “Parents’ Extrafamilial Resources and Children’s School Attainment.” Sociology of Education 71(3):246-68. doi: 10.2307/2673204.

Holland, Megan M. 2015. “Trusting Each Other: Student-Counselor Relationships in Diverse High Schools.” Sociology of Education 88(3):244-62. doi: 10.1177/0038040715591347.

Holland, Megan M. 2019. Divergent Paths to College: Race, Class, and Inequality in High Schools. Rutgers University Press.

Horvat, Erin McNamara, Elliot B. Weininger, and Annette Lareau. 2003. "From Social Ties to Social Capital: Class Differences in the Relations Between Schools and Parent Networks.” American Educational Research Journal 40(2):319-51. doi: 10.3102/00028312040002319.

Hu, Anning, and Chen Yin. 2020. "The Distinction between the Absolute and Relative Advantages of Cultural Capital: Different Conceptualizations, Different Consequences.” Sociology 0038038520973588 . doi: 10.1177/0038038520973588.

Jack, Anthony Abraham. 2014. "Culture Shock Revisited: The Social and Cultural Contingencies to Class Marginality.” Sociological Forum 29(2):453-75. doi: https://doi.org/10.1111/socf.12092. 
Jack, Anthony Abraham. 2016. “(No) Harm in Asking: Class, Acquired Cultural Capital, and Academic Engagement at an Elite University.” Sociology of Education 89(1):1-19. doi: $10.1177 / 0038040715614913$.

Jack, Anthony Abraham. 2019. The Privileged Poor: How Elite Colleges Are Failing Disadvantaged Students. Harvard University Press.

Jackson, Matthew O. 2020. “A Typology of Social Capital and Associated Network Measures.” Social Choice and Welfare 54(2):311-36. doi: 10.1007/s00355-019-01189-3.

Jæger, Mads Meier. 2009. "Equal Access but Unequal Outcomes: Cultural Capital and Educational Choice in a Meritocratic Society.” Social Forces 87(4):1943-71. doi: 10.1353/sof.0.0192.

Jæger, Mads Meier. 2011. "Does Cultural Capital Really Affect Academic Achievement? New Evidence from Combined Sibling and Panel Data.” Sociology of Education 84(4):281-98. doi: $10.1177 / 0038040711417010$.

Kisida, Brian, Jay P. Greene, and Daniel H. Bowen. 2014. “Creating Cultural Consumers The Dynamics of Cultural Capital Acquisition.” Sociology of Education 0038040714549076. doi: $10.1177 / 0038040714549076$.

Kozlowski, Karen Phelan. 2015. "Culture or Teacher Bias? Racial and Ethnic Variation in StudentTeacher Effort Assessment Match/Mismatch.” Race and Social Problems 7(1):43-59. doi: 10.1007/s12552-014-9138-x.

Kwon, Seok-Woo, and Paul S. Adler. 2014. "Social Capital: Maturation of a Field of Research.” Academy of Management Review 39(4):412-22. doi: 10.5465/amr.2014.0210.

Lakon, Cynthia M., Dionne C. Godette, and John R. Hipp. 2008. "Network-Based Approaches for Measuring Social Capital.” Pp. 63-81 in Social Capital and Health, edited by I. Kawachi, S. V. Subramanian, and D. Kim. New York, NY: Springer.

Lamont, Michele, and Annette Lareau. 1988. "Cultural Capital: Allusions, Gaps and Glissandos in Recent Theoretical Developments.” Sociological Theory 6(2):153-68. doi: 10.2307/202113.

Lareau, Annette. 2000. Home Advantage: Social Class and Parental Intervention in Elementary Education. 2nd ed. Rowman \& Littlefield Publishers.

Lareau, Annette. 2011. Unequal Childhoods: Class, Race, and Family Life. 2nd ed. University of California Press.

Lareau, Annette. 2015. "Cultural Knowledge and Social Inequality.” American Sociological Review 80(1):1-27. doi: 10.1177/0003122414565814.

Lareau, Annette, and Jessica McCrory Calarco. 2012. "Class, Cultural Capital, and Institutions: The Case of Families and Schools.” Pp. 61-86 in Facing Social Class: How Societal Rank Influences Interaction, edited by S. T. Fiske and H. R. Markus. Russell Sage Foundation.

Lareau, Annette, and Elliot B. Weininger. 2003. “Cultural Capital in Educational Research: A Critical Assessment.” Theory and Society 32(5-6):567-606. doi:

10.1023/B:RYSO.0000004951.04408.b0. 
Lee, Elizabeth M., and Rory Kramer. 2013. "Out with the Old, In with the New? Habitus and Social Mobility at Selective Colleges.” Sociology of Education 86(1):18-35. doi:

10.1177/0038040712445519.

Lehmann, Wolfgang. 2014. "Habitus Transformation and Hidden Injuries Successful Working-Class University Students.” Sociology of Education 87(1):1-15. doi: 10.1177/0038040713498777.

Lin, Nan. 2002. Social Capital: A Theory of Social Structure and Action. Cambridge University Press.

Lin, Nan. 2008. “A Network Theory of Social Capital.” Pp. 50-69 in The Handbook of Social Capital, edited by D. Castiglione, J. W. Van Deth, and G. Wolleb. New York, NY: Oxford University Press.

Lin, Nan, Walter M. Ensel, and John C. Vaughn. 1981. "Social Resources and Strength of Ties: Structural Factors in Occupational Status Attainment.” American Sociological Review 46(4):393-405. doi: 10.2307/2095260.

Matsuoka, Ryoji. 2019. “Concerted Cultivation Developed in a Standardized Education System.” Social Science Research 77:161-78. doi: 10.1016/j.ssresearch.2018.08.011.

McDonald, Steve, S. Michael Gaddis, Lindsey B. Trimble, and Lindsay Hamm. 2013. "Frontiers of Sociological Research on Networks, Work, and Inequality.” Pp. 1-41 in Networks, Work and Inequality. Vol. 24, Research in the Sociology of Work, edited by S. Mcdonald. Emerald Group Publishing Limited.

McNeal, Ralph B. 1999. "Parental Involvement as Social Capital: Differential Effectiveness on Science Achievement, Truancy, and Dropping Out.” Social Forces 78(1):117-44. doi: 10.1093/sf/78.1.117.

Morgan, Stephen L., and Aage B. Sørensen. 1999. "Parental Networks, Social Closure, and Mathematics Learning: A Test of Coleman's Social Capital Explanation of School Effects.” American Sociological Review 64(5):661-81. doi: 10.2307/2657368.

Mouw, Ted. 2003. “Social Capital and Finding a Job: Do Contacts Matter?” American Sociological Review 68(6):868-98. doi: 10.2307/1519749.

Mouw, Ted. 2006. "Estimating the Causal Effect of Social Capital: A Review of Recent Research.” Annual Review of Sociology 32(1):79-102. doi: 10.1146/annurev.soc.32.061604.123150.

Noble, John, and Peter Davies. 2009. "Cultural Capital as an Explanation of Variation in Participation in Higher Education.” British Journal of Sociology of Education 30(5):591-605. doi: 10.1080/01425690903101098.

Nora, Amaury. 2004. “The Role of Habitus and Cultural Capital in Choosing a College, Transitioning From High School to Higher Education, and Persisting in College Among Minority and Nonminority Students.” Journal of Hispanic Higher Education 3(2):180-208. doi: $10.1177 / 1538192704263189$.

Parcel, Toby L., and Mikaela J. Dufur. 2001. “Capital at Home and at School: Effects on Student Achievement*." Social Forces 79(3):881-911. doi: 10.1353/sof.2001.0021. 
Pedulla, David S., and Devah Pager. 2019. "Race and Networks in the Job Search Process.” American Sociological Review 84(6):983-1012. doi: 10.1177/0003122419883255.

Portes, Alejandro. 1998. "Social Capital: Its Origins and Applications in Modern Sociology.” Annual Review of Sociology 24(1):1-24. doi: 10.1146/annurev.soc.24.1.1.

Ream, Robert K., and Gregory J. Palardy. 2008. "Reexamining Social Class Differences in the Availability and the Educational Utility of Parental Social Capital.” American Educational Research Journal 45(2):238-73. doi: 10.3102/0002831207308643.

Richards, Bedelia Nicola. 2020a. "Help-Seeking Behaviors as Cultural Capital: Cultural Guides and the Transition from High School to College among Low-Income First Generation Students.” Social Problems (spaa023). doi: 10.1093/socpro/spaa023.

Richards, Bedelia Nicola. 2020b. "When Class Is Colorblind: A Race-Conscious Model for Cultural Capital Research in Education.” Sociology Compass 14(7):e12789. doi: 10.1111/soc4.12786.

Rivera, Lauren A. 2011. “Ivies, Extracurriculars, and Exclusion: Elite Employers’ Use of Educational Credentials.” Research in Social Stratification and Mobility 29(1):71-90. doi: 10.1016/j.rssm.2010.12.001.

Rivera, Lauren A. 2012. "Hiring as Cultural Matching The Case of Elite Professional Service Firms.” American Sociological Review 77(6):999-1022. doi: 10.1177/0003122412463213.

Roksa, Josipa, and Daniel Potter. 2011. "Parenting and Academic Achievement Intergenerational Transmission of Educational Advantage.” Sociology of Education 84(4):299-321. doi: $10.1177 / 0038040711417013$.

Sablan, Jenna R., and William G. Tierney. 2014. “The Changing Nature of Cultural Capital.” Pp. 153-88 in Higher Education: Handbook of Theory and Research, Higher Education: Handbook of Theory and Research, edited by M. B. Paulsen. Springer Netherlands.

Sandefur, Gary D., Ann M. Meier, and Mary E. Campbell. 2006. "Family Resources, Social Capital, and College Attendance.” Social Science Research 35(2):525-53. doi: 10.1016/j.ssresearch.2004.11.003.

Smith, Sandra Susan. 2008. "A Question of Access or Mobilization? Understanding Inefficacious Job Referral Networks among the Black Poor.” Pp. 157-81 in Social Capital: An International Research Program, edited by N. Lin and B. H. Erickson.

Stanton-Salazar, Ricardo. 1997. "A Social Capital Framework for Understanding the Socialization of Racial Minority Children and Youths.” Harvard Educational Review 67(1):1-41. doi: 10.17763/haer.67.1.140676g74018u73k.

Stanton-Salazar, Ricardo D. 2001. Manufacturing Hope and Despair: The School and Kin Support Networks of U.S.-Mexican Youth. Teachers College Press.

Stanton-Salazar, Ricardo D. 2011. "A Social Capital Framework for the Study of Institutional Agents and Their Role in the Empowerment of Low-Status Students and Youth.” Youth \& Society 43(3):1066-1109. doi: 10.1177/0044118X10382877. 
Stanton-Salazar, Ricardo D., and Sanford M. Dornbusch. 1995. "Social Capital and the Reproduction of Inequality: Information Networks among Mexican-Origin High School Students.” Sociology of Education 68(2):116-35. doi: 10.2307/2112778.

Stephens, Nicole M., Sarah S. M. Townsend, Hazel Rose Markus, and L. Taylor Phillips. 2012. “A Cultural Mismatch: Independent Cultural Norms Produce Greater Increases in Cortisol and More Negative Emotions among First-Generation College Students.” Journal of Experimental Social Psychology 48(6):1389-93. doi: 10.1016/j.jesp.2012.07.008.

Stevens, Mitchell L. 2007. Creating a Class: College Admissions and the Education of Elites. Harvard University Press.

Streib, Jessi. 2011. “Class Reproduction by Four Year Olds.” Qualitative Sociology 34(2):337-52. doi: 10.1007/s11133-011-9193-1.

Stuber, Jenny M. 2011. Inside the College Gates: How Class and Culture Matter in Higher Education. Lexington Books.

Teachman, Jay D., Kathleen Paasch, and Karen Carver. 1996. "Social Capital and Dropping Out of School Early.” Journal of Marriage and Family 58(3):773-83. doi: 10.2307/353735.

Tramonte, Lucia, and J. Douglas Willms. 2010. "Cultural Capital and Its Effects on Education Outcomes.” Economics of Education Review 29(2):200-213. doi:

10.1016/j.econedurev.2009.06.003.

Van der Gaag, Martin, and Tom Snijders. 2004. "Proposals for the Measurement of Individual Social Capital.” in Creation and Returns of Social Capital, edited by H. Flap and B. Völker. Routledge.

Wildhagen, Tina. 2009. "Why Does Cultural Capital Matter for High School Academic Performance? An Empirical Assessment of Teacher-Selection and Self-Selection Mechanisms as Explanations of the Cultural Capital Effect.” The Sociological Quarterly 50(1):173-200. doi: 10.1111/j.15338525.2008.01137.x.

Yee, April. 2016. “The Unwritten Rules of Engagement: Social Class Differences in Undergraduates' Academic Strategies.” The Journal of Higher Education 87(6):831-58. doi: 10.1080/00221546.2016.11780889.

Zarifa, David, Jeannie Kim, Brad Seward, and David Walters. 2018. "What’s Taking You So Long? Examining the Effects of Social Class on Completing a Bachelor's Degree in Four Years." Sociology of Education 91(4):290-322. doi: 10.1177/0038040718802258. 